\title{
EVOLUŢIE SEVERĂ CU MULTIPLE DETERMINĂRI SEPTICE LA UN PACIENT DIAGNOSTICAT CU INFECŢIE CU STREPTOCOCCUS GALLOLYTICUS
}

Constantin Marilena ${ }^{1}$, Neața Mădălina ${ }^{1}$, Ștefan Liliana ${ }^{1}$, Acatrinei Eliza ${ }^{1}$, Bumbu Aurelia $^{2}$, Enyedi Mihai ${ }^{1}$, Nica Maria ${ }^{1}$, Voinea Cristina ${ }^{1}$, Calistru Petre ${ }^{1}$

${ }^{I}$ Fundația "Dr. Victor Babeș"

${ }^{2}$ Spitalul Clinic de Boli Infecțioase și Tropicale "Dr. Victor Babeş"

\begin{abstract}
REZUMAT
Streptococcus gallolyticus, membru al grupului Streptococcus bovis (strepococ de grup D) colonizează tubul digestiv al păsărilor, animalelor rumegătoare şi om (2,5-15\%). Este descrisă în literatură asocierea bacteriemiei cu Streptococcus gallolyticus cu tumori colonice şi manifestări extracolonice (endocardită bacteriană, osteomielită vertebrală, discită, colangite, tumori pulmonare, ovariene).

Raportăm cazul unui pacient în vârstă de 60 ani, sex masculin, caucazian, la care infecţia cu Streptococcus Gallolyticus identificată prin hemocultură a avut ca primă manifestare osteomielită vertebrală.

S-au identificat leziuni la nivelul valvei aortice (endocardită bacteriană), arterei politee dreapta (tromboză diagnosticată prin ecografie Doppler artere, angio CT membre pelvine), genunchi drept (artrită). Deşi evoluţia a fost favorabilă din punct de vedere clinic (afebrilitate, ameliorarea durerii lombare) şi biologic

(scăderea leucocitozei, a sindromului inflamator, hemoculturile ulterioare au fost negative) repetarea investigaţiilor imagistice la 30 zile şi la 45 zile au arătat insuficienţă aortică severă ce a necesitat intervenţie chirurgicală pentru înlocuire de valvă aortică efectuată la 2 luni de la diagnostic. Leziunile de la nivelul coloanei vetebrale, arterei poplitee s-au ameliorat după 2 luni de tratament antibiotic. Colonoscopia efectuată la 6 săptămîni de la diagnostic a arătat prezenţa polipilor colonici - posibilă poartă de intrare pentru Streptococcus gallolyticus.

Cazul prezentat demonstrează debutul silenţios al infecţiei cu Streptococcus gallolyticus, evoluţia ulterioară severă din cauza multiplelor determinări septice şi atrage atenţia asupra necesităţii efectuării explorărilor digestive (endoscopie digestivă superioară, colonoscopie) la pacienţii diagnosticaţi cu acest tip de infecţie.
\end{abstract}

Cuvinte cheie: Infecţie cu Streptococcus gallolyticus, osteomielită vertebrală, endocardită, tromboză

\section{INTRODUCERE}

Streptococcus gallolyticus, membru al grupului Streptococcus bovis (strepococ de grup D) este un microorganism oportunist care colonizează tubul digestiv al păsărilor, animalelor rumegătoare și om, și care în prezența unor factori favorizanți (leziuni colonice incipiente) produce bacteriemie cu determinări septice multiple. Infecția cu Streptococcus gallolyticus se asociază cu neoplasme gastrointestinale (polipi și carcinoame de colon) diagnosticate de obicei după episoade de endocardită și răspunde la tratamentul cu Penicilină (5).

Datele din literatura de specialitate arată că 25-80\% din pacienții cu S. bovis au tumori colorectale, 18-62\% din pacienți au asociat endocardită bacteriană și neoplasm de colon, 94\% din bacteriemiile cu S. bovis care au asociat tumori colorectale au aparținut biotipului 1 (Streptococcus gallolyticus) (1). 
În 1951 Mc Coy și Mason sugerează relația dintre carcinomul de colon și endocardita infecțioasă, iar în 1974 se recunoaște asocierea dintre S. bovis și neoplasmul colorectal (1).

Manifestările extracolonice cele mai frecvente au fost osteomielita, discita și abcesele gâtului (1).

Sunt descrise în literatură posibile mecanisme prin care Streptococcus gallolyticus este implicat în apariția cancerului de colon și endocarditei bacteriene: inflamația cronică, stimularea angiogenezei, creșterea permeabilității vasculare, proliferare celulară necontrolată. Streptococcus gallolyticcus posedă două elemente esențiale de virulență reprezentate de capsula polizaharidică și structurile de tip pili care îi conferă capacitate de traslocare paracelulară crescută, capacitate de ocolire a sistemului imun nespecific și rezistență față de sistemul complementului, ceea ce îi permite supraviețuirea în circulația sanguină și fixarea la nivelul endocardului cu formare de biofilm.

\section{STUDIU DE CAZ}

Pacient în vârstă de 60 de ani s-a prezentat la o evaluare medicală în ambulator cu durere lombară dreapta intensă în iulie 2015. Anamneza a relevat astenie fizică și scădere ponderală de aproximativ 6-7 kg în ultimele 3-4 luni. Din istoricul medical se rețin un episod de anita în iunie 2015, episod de diplopie în iunie 2015, infecție de tract urinar cu E. Coli pentru care a urmat tratament cu Zinnat în iunie 2015, ruptură de menisc stâng operată în urmă cu 20 ani. Pacientul este fumător 10-15 tigări de foi de 20 ani, consumă alcool ocazional.

Din antecedentele heredocolaterale reținem: mama decedată la 77 de ani cu neoplasm intestin, tata decedat la 92 de ani cu tumoră pulmonară, sora decedată cu leucemie.

Clinic la prezentare s-au constatat pacient $\mathrm{cu}$ exces ponderal $(\mathrm{T}=187 \mathrm{~cm}$; $\mathrm{G}=100 \mathrm{~kg}$; $\mathrm{BMI}=28,7 \mathrm{~kg} / \mathrm{m}^{2}$ ), cu stare generală medie, tegumente și mucoase palide, fără adenopatii palpabile; pulmonar - normal; $\mathrm{AV}=64 / \mathrm{min}$, ritmic;
TA=100/70 mmHg; abdomen suplu, sensibil la palpare în flancul drept și lomba dreaptă.

Analizele efectuate au relevant neutrofilie $\mathrm{L}=9170 / \mathrm{mm} 3$ ( $\mathrm{N}=87,7 \%$; lym=9,4\%); sindrom inflamator $(\mathrm{VSH}=51 \mathrm{~mm} / \mathrm{h}$; fib=552 $\mathrm{mg} / \mathrm{dl}$; $\mathrm{CRP}=8,3 \mathrm{mg} / \mathrm{dl}$; EPS: proteine totale $=7,2 \mathrm{~g} / \mathrm{dl}$; $\mathrm{alb}=55,9 \%$; alfa $1=4,3 \%$; sideremie $65 \mathrm{mcg} / \mathrm{dl}$; feritină serică 903 mcg/dl (20-290); CTLF=219 $\mathrm{mcg} / \mathrm{dl}$ (261-462); gamaglobuline=17,7\%); FR pozitiv; splenomegalie (ecografie abdominală).

Se efectuează RMN coloană lombară care descrie modificări degenerativ productive ale coloanei vertebrale lombare; anterolistezis L5-S1; debord discal L4-L5 ce determină contact discoradicular cu rădăcinile L5 bilateral intracanalar; hernie de disc L5-S1 ce determină împreună cu anterolistezisul descris compresiunea rădăcinilor L5 bilateral la nivelul găurilor de conjugare.

Pentru episodul de diplopie se efectuează RMN cerebral (leziuni demielinizante nespecifice milimetrice dispuse subcortical frontal bilateral) și consult neurologic cu recomandare de ecografie Doppler transcranian.

Examenul clinic și investigațiile efectuate au orientat spre diagnosticul de: hernie de disc L5-S1; anterolistezis L5-S1; sindrom inflamator. Consulturile de specialitate și analizele efectuate au exclus alte cauze de sindrom inflamator (reumatică, hematologică, pulmonară, afecțiune a prostatei).

Sub tratament cu AINS și antialagic durerea persistă și apare stare febrilă motiv pentru care pacientul se internează.

Clinic la internare s-a constatat pacient $\mathrm{cu}$ stare generală medie, febril (38,3 grd. C); tegumente și mucoase normal colorate; fără adenopatii palpabile; pulmonar normal; $A V=96 / \mathrm{min}$, ritmic; $\mathrm{TA}=120 / 60 \mathrm{mmHg}$; artere pedidoase palpabile; abdomen suplu, mobil cu respirația, nedureros la palpare; orientat temporospatial; Laseque pozitiv la 70 grd.

Investigațiile efectuate la internare au indicat: leucocitoză $(16.200 / \mathrm{mcl})$ cu neutrofilie (86\%) și limfopenie $(7,4 \%)$; frotiul de sânge 
periferic descrie la nivelul seriei leucocitare: nesegmentate $2 \%$, neutrofile $88 \%$, limfocite $6 \%$, monocite $4 \%$ cu serie eritrocitară cu aspect morfologic normal și macrotrombocite; trombocitopenie $\left(141.000 / \mathrm{mm}^{3}\right)$; sindrom inflamator (VSH=37 mm/h; fib=488 mg/dl; CRP 3,3 mg/dl) rare hematii și eritrocite în examenul sumar urină; urocultură sterilă.

Ecocardiografia la internare a relevat ventricul stâng nedilatat cu funcție sistolică globală și segmentară normale, disfuncţie diastolică tip alterarea relaxării, regurgitare aortică ușoară, fără HTAP, fără imagini sugestive de vegetații la ecografia transtoracică. S-a recoltat hemocultură (Tabelul 1).

Persistența durerii la nivelul lombei drepte și a stării febrile au determinat repetarea RMN lombar (Fig. 1).

A doua zi de la internare pacientul descrie durere la nivelul gambei stângi în ortostatism cu ameliorare în clinostatism și în poziție antigravitațională. Recoltarea testului pentru D-dimeri care a fost intens pozitiv (3589 $\mathrm{ng} / \mathrm{ml}$ ), efectuarea de eco Doppler vene și artere membre inferioare și angio CT pentru membre pelvine stabilesc diagnosticul de tromboză de arteră poplitee stângă.

CT-ul de torace cu substanță de contrast a exclus trombembolia pulmonară.

Tabelul 1.

\begin{tabular}{|l|c|l|}
\hline Benzylpenicili & CMI & interpretare \\
\hline Benzylpenicili & $\leq 0.6$ & $\mathrm{~S}$ \\
\hline Ampicillin & $\leq 0.25$ & $\mathrm{~S}$ \\
\hline Cefotaxim & $\leq 0.12$ & $\mathrm{~S}$ \\
\hline Ceftriaxon & $\leq 0.12$ & $\mathrm{~S}$ \\
\hline Levofloxacin & 4 & $\mathrm{I}$ \\
\hline Erithromicin & $\leq 0.12$ & $\mathrm{~S}$ \\
\hline Clindamycin & $\leq 0.25$ & $\mathrm{~S}$ \\
\hline Linezolid & $\leq 2$ & $\mathrm{~S}$ \\
\hline Vancomycin & 0.25 & $\mathrm{~S}$ \\
\hline Tetracycline & $\geq 0.16$ & $\mathrm{R}$ \\
\hline
\end{tabular}

- S-au recoltat hemoculturi care s-au pozitivat pentru Streptococcus gallolyticus la 4 zile de la internare.

- Antibiograma (standard difuzimetrica cantitativă cu determinare valori CMI (sistem automat VITEK 2C/ carduri de antibiogramă AST-ST01S și metoda E test).

- Conform standard CLSI 2015
Se inițiază tratament anticoagulant cu enoxaparină în doze terapeutice și se efectuează consult de chirurgie vasculară care recomandă terapie anticoagulantă cu heparină în doze terapeutice, arteriografie și consult de cardiologie intervențională pentru a decide oportunitatea unei revascularizări intervenționale. Nu s-a recomandat intervenție chirurgicală în urgență.

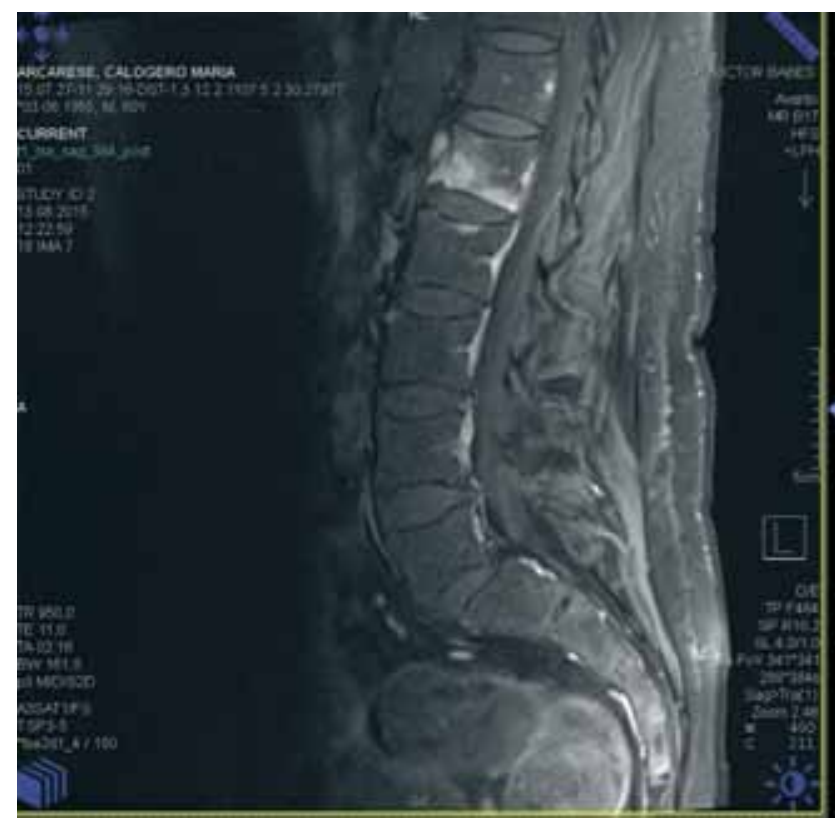

Figura 1. RMN lombar descrie un proces cu caracter inflamator la nivelul vertebrei $L 1$

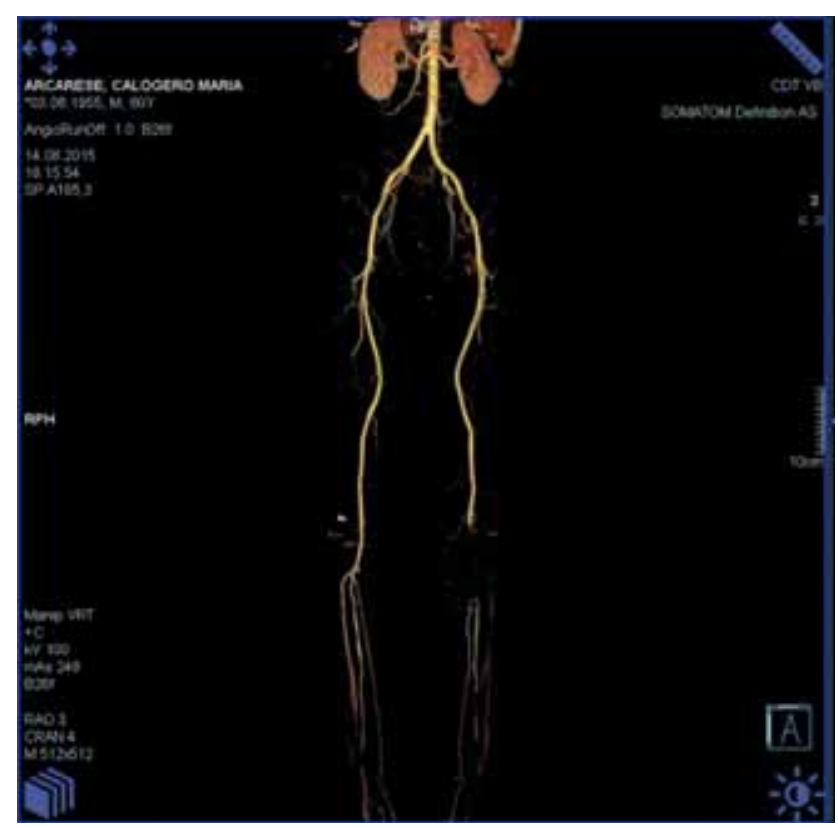

Figura 2. Angio CT pentru membre pelvine descrie artera poplitee stg. cu flux absent în porțiunea terminală la emergențele și porțiunile proximale ale arterelor tibiale anterioară, posterioară și fibulara până la unirea 1/3 sup. cu 2/3 inf. ale gambei cu minime calcificări 
Repetarea ecocardiografiei transtoracice în ziua a șasea de spitalizare a descris formațiuni mobile de 9 și $4 \mathrm{~mm}$ atașate de valva aortică. S-a inițiat tratament pentru endocardită infecțioasă cu Penicilină G 18 milioane/zi (în 6 doze) și Gentamicină 240 mg/zi (în 3 doze). Ecocardiografia transesofagiană efectuată 2 zile mai târziu a arătat vâlvă aortică impregnată mixomatos cu două formațiuni lineare de maximum $9 \mathrm{~mm}$ și 4 $\mathrm{mm}$ cu aspect de vegetații.

Având în vedere contextul clinic al pacientului și incertitudinea sterilității vegetațiilor descrise se opinează pentru continuarea tratamentului conform protocolului de endocardită infecțioasă. S-a considerat că pacientul nu are indicație chirurgicală la momentul evaluării. După 10 zile de tratment s-a încercat scăderea dozelor de Penicilină la 12 milioane/zi, dar reapare febra însoțită de un episod de artrită la nivelul genunchiului stâng (Tabelul 2).

Pe durata internării s-au monitorizat temperatura (la 4 ore), TA, AV. Pacientul a fost evaluat periodic prin ECG, ecocardiografie transtoracică, eco Doppler artere membre inferioare, evoluția sindromului inflamator prin determinare CRP în dinamică.

Pacientul a primit recomandări privind mobilizare minimă, purtare corset toracolombar Hessing, mobilizare pasivă membre inferioare, hidratare po.

În ceea ce privește tratamentul antibiotic s-a respectat protocolul de tratament al endocarditei bacteriene, dar având în vedere leziunile vertebrale s-a menținut tratamentul cu fluorochinoloa și aminopenicilină pînă la 6 luni. Tratamentul asociat a constat în: enoxaparină, aspirină, pantoprazol, gabapentin, alanerv, probiotic (Tabel 3).
Tabelul 2. Diagnostic pozitiv

\begin{tabular}{|l|l|}
\hline Sepsis & $\begin{array}{l}\text { 4 criterii: } \\
\text { febră> 38 grd. C; tahicardie> 90 bpm; } \\
\text { leucocitoză> 12000/mm3; hemocultură } \\
\text { pozitivă. }\end{array}$ \\
\hline $\begin{array}{l}\text { Endocardita } \\
\text { bacteriana cu } \\
\text { Streptococcus } \\
\text { Gallolyticus }\end{array}$ & $\begin{array}{l}\text { Criteriile Duke: } \\
\text { un criteriu major :ecocardiografia } \\
\text { 4 criterii minore :febră >=38 grd.C, } \\
\text { fenomene vasculare( embolie arterială } \\
\text { majoră), fenomene imunologice( factor } \\
\text { reumatoid prezent), criterii microbiologice } \\
\text { (hemoculturi pozitive) fără a întruni } \\
\text { criteriile majore }\end{array}$ \\
\hline $\begin{array}{l}\text { Osteomielita } \\
\text { vertebrală }\end{array}$ & $\begin{array}{l}\text { febră; durere lombară; sindom inflamator; } \\
\text { hemoculturi pozitive; imagine RMN } \\
\text { lombar; factori predispozanţi(modificări } \\
\text { degenerative ale coloanei lombare) }\end{array}$ \\
\hline $\begin{array}{l}\text { Tromboză arteră } \\
\text { poplitee }\end{array}$ & $\begin{array}{l}\text { D-dimeri pozitivi; eco Doppler artere } \\
\text { membre inferioare; angio CT }\end{array}$ \\
\hline $\begin{array}{l}\text { Artrită genunchi } \\
\text { stâng }\end{array}$ & Clinic:tumefacţie, inflamaţie, durere \\
\hline $\begin{array}{l}\text { Hernie de disc } \\
\text { L5-S1 }\end{array}$ & RMN lombar \\
\hline
\end{tabular}

Figura 3. Ecografia transesofagiana descrie insuficienta aortica severa, formatiune hipoecogena cu mobilitate proprie cu aspect sugestiv pentru vegetatie; valva mitrala de aspect normal cu regurgitareAS moderat dilatat; VS dilatat $61 / 44 \mathrm{~mm}$

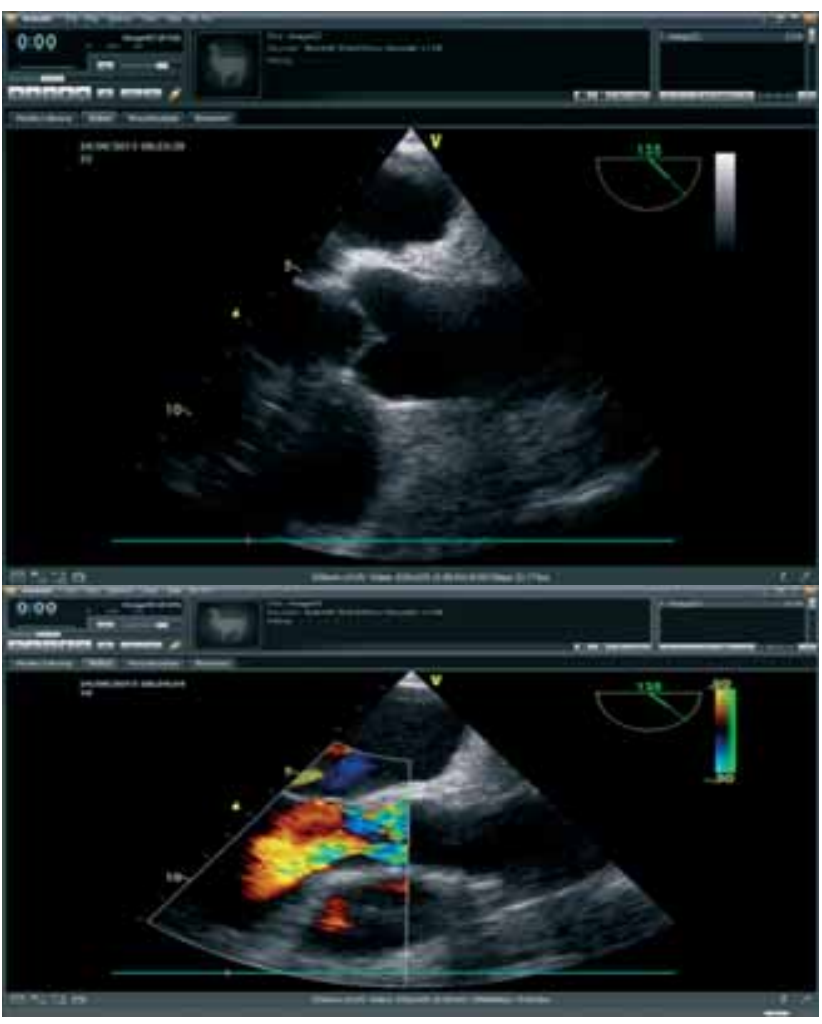

Tabelul 3. Tratament antibiotic pe durata spitalizării

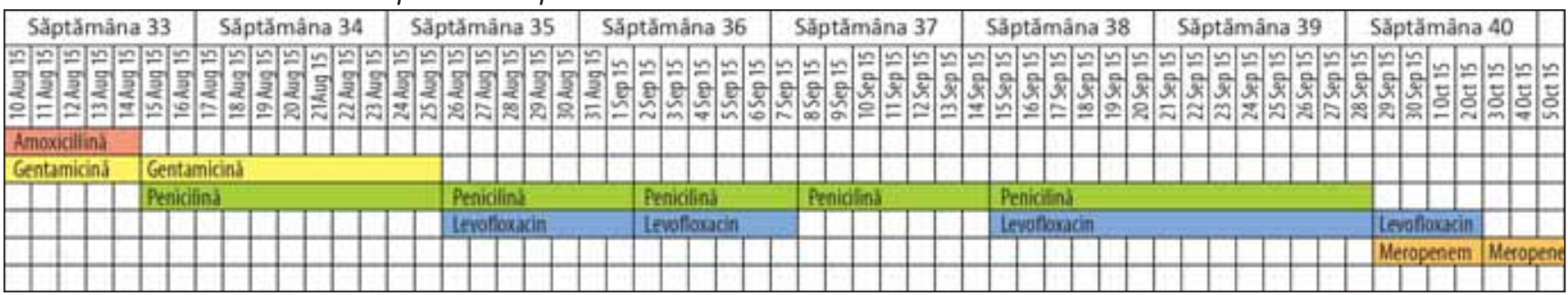


Evoluția sub tratament a fost favorabilă din punct de vedere clinic (pacient afebril, cu durere lombară ameliorată, cu remiterea durerii la nivelul gambei stângi și a fenomenelor inflamatorii la nivelul genunchiului stâng) și biologic (remiterea sindromului inflamator), dar ecocardiografiile transtoracică și transesofagiană repetate după 40 zile de tratament cu Penicilină descriu insuficiență aortică severă cu indicație de înlocuire de valvă aortică (Fig. 3).

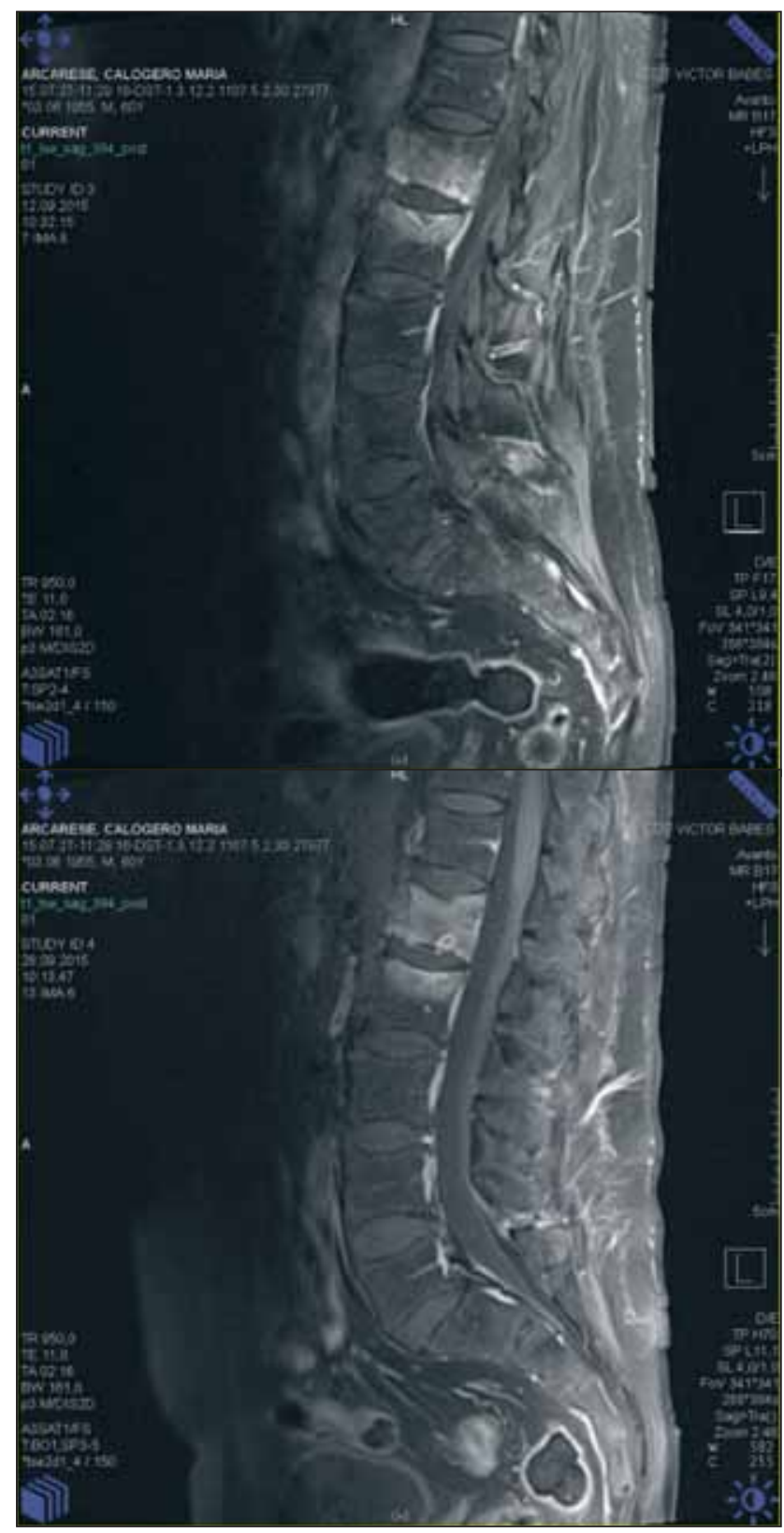

Figura 4. RMN-ul de coloană lombară şi bazin descrie modificări edematos inflamatorii localizate la nivelul discului intervertebral T12-L2 şi platourilor vertebrale adiacente cu aspect IRM compatibil cu osteodiscita în uşoară progresie faţă de examinarea din 12.09.2015 precum şi modificări de statică şi degenerativ productive ale coloanei vertebrale lombare
RMN-ul de coloană lombară a arătat menținerea leziunilor vertebrale în ușoară progresie față de examinarea anterioară (Fig. 4).

RMN-ul de coloană lombară și bazin descrie modificări edematos inflamatorii localizate la nivelul discului intervertebral T12-L2 și platourilor vertebrale adiacente cu aspect IRM compatibil cu osteodiscita în ușoară progresie față de examinarea din 12.09.2015 precum și modificări de statică și degenerativ productive ale coloanei vertebrale lombare.

$\mathrm{S}$-a menținut imaginea de tromb la nivelul arterei poplitee stânga.

Ecografia Doppler pentru artera poplitee stânga a fost repetată la 45 zile de spitalizare și nu a arătat modificări semnificative la nivelul trombusului.

În octombrie 2015 pacientul este internat la sopitalul Niguarda - Milano unde s-a efectuat înlocuirea valvei aorte cu proteză biologică (NB: vegetații sterile la momentul intervenției chirurgicale) cu evoluție postoperatorie favorabilă. Colonoscopia efectuată la spitalul Niguarda a identificat doi polipi colonici și s-a practicat polipectomie (examen histopatologic în lucru).

Deasemenea s-a repetat ecografia Doppler arteră poplitee stânga care a arătat repermeabilizarea parțială a acesteia.

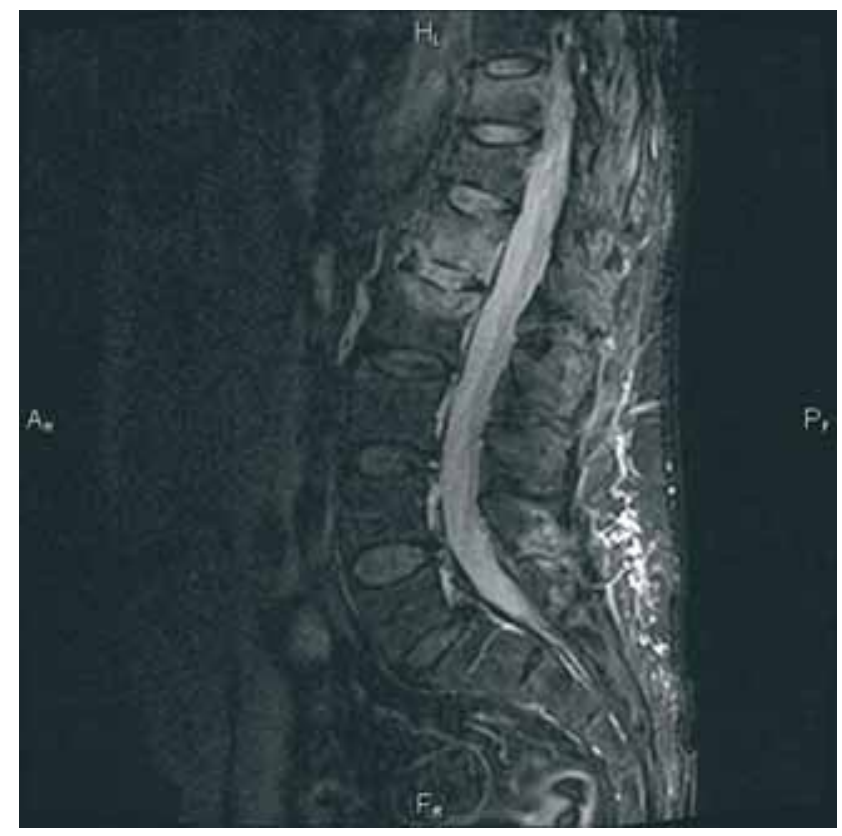

Figura 5. Leziuni T12-L5 compatibile cu osteodiscită ameliorate; imaginea T11 nemodificată 
Ultimul RMN coloană lombară efectuat la 3 luni și 2 săptămâni de la inițierea tratamentului antibiotic arată ameliorarea leziunilor la nivelul coloanei lombare (Fig. 5).

\section{DISCUTुII}

Cazul prezentatat a constituit o problemă de diagnostic și tratament. Durerea lombară putea fi explicată prin modificările descrise la RMN-ul de coloană lombară, dar prezența sindromului inflamator, starea de astenie fizică și scăderea ponderală au impus efectuarea altor investigații care au relevat prezența factorului reumatoid pozitiv și a splenomegaliei. Apariția febrei a reprezentat un element cheie pentru diagnostic, asocierea acesteia cu lombalgia și sindromul inflamator determinând repetarea RMN-ului lombar cu stabilirea diagnosticului de osteomielită vertebrală. Consultarea literaturii de specialitate a arătat asocierea osteomielitei cu endocardita bacteriană. Al doilea element cheie a fost reprezentat de identificarea Streptococcus gallolyticus în hemocultură, fiind cunoscută în literatură asocierea acestuia cu endocardită bacteriană. Cunoașterea datelor din literarură a determinat inițierea protocolului de tratament pentru endocardită bacteriană înainte de a stabili diagnosticul de certitudine ulterior ecografia transesofagiană confirmînd prezența vegetațiilor la nivelul valvei aortice. Tromboza arterei poplitee și artrita genunchiului stâng au fost determinări septice ale endocarditei bacteriene.

Terapia cu antibiotice s-a desfășurat pe o perioadă de 6 luni luându-se în considerare antibiograma, schemele de tratament pentru endocardita bacteriană și gradul de difuziune al antibioticului la nivelul țesutului osos.

În acest caz ne-am pus întrebarea asupra modului în care Streptococcus gallolyticus a determinat bacteriemie. Datele din literatură $(1,2)$ arată asocierea bacteriemiei cu Streptococcus gallolyticus cu tumori colonice. Deși inițial starea generală a pacientului nu a permis efectuarea colonoscopiei aceasta s-a efectuat la 2 luni de la diagnostic și a confirmat prezența polipilor colonici - posibilă poartă de intrare a agentului patogen. De menționat că determinările septice au apărut în zonele cu leziuni preexistente (la nivelul coloanei lombare pe zone cu osteofitoză, la nivelul genunchiului unde s-a efectuat intervenția chirurgicală pentru ruptură de menisc).

Revenind la datele din literatură, relația Streptococcus gallolyticus - tumori colorectale endocardită bacteriană are ca element central colagenul de tip IV prezent la nivelul membranei bazale a mucoasei colonice și endocard (bacteria colonizează $10 \%$ din populația normală, dar se întâlnește la peste 55\% din pacienții cu leziuni colonice) pe care Streptococcus gallolyticus se fixează prin structurile de tip pili cu formare de biofilm (2).

Particularitatea cazului rezultă din dificultatea stabilirii diagnosticului și a elaborării planului terapeutic în contextul apariției manifestărilor septice multiple (endocardită, osteomielită, artrită, tromboză arterială) după o evoluție silențioasă a infecției cu Streptococcus gallolyticus (astenie fizică, subfebrilitate, scădere ponderală). Manifestările extracolonice au precedat identificarea patologiei colonice (colonoscopia efectuată ulterior a identificat polipi colonici - posibilă poartă de intrare pentru agentul etiologic).

Acest caz ilustrează gravitatea infecției cu Streptococcus gallolyticus și atrage atenția asupra necesității efectuării explorărilor digestive (colonoscopie, endoscopie digestivă superioară) la pacienții diagnosticați cu acest tip de infecție. 